\title{
ANIMAL RESEARCH PAPER Agronomic traits, ensilability and nutritive value of five pearl millet cultivars grown in a Brazilian semi-arid region
}

\author{
R. D. DOS SANTOS ${ }^{1,7 *}$, A. L. A. NEVES ${ }^{2}$, L. G. R. PEREIRA ${ }^{2}$, L. E. SOLLENBERGER ${ }^{3}$, \\ J. A. S. RODRIGUES ${ }^{4}$, J. N. TABOSA ${ }^{5}$, R. S. VERNEQUE ${ }^{2}$, G. F. OLIVEIRA ${ }^{6}$, D. G. JAYME ${ }^{7}$ \\ AND L. C. GONÇALVES ${ }^{7}$ \\ ${ }^{1}$ Embrapa Semi-Arid, Brazilian Agricultural Research Corporation (Embrapa), Petrolina, Pernambuco, Brazil \\ ${ }^{2}$ Embrapa Dairy Cattle, Brazilian Agricultural Research Corporation (Embrapa), Juiz de Fora, Minas Gerais, Brazil \\ ${ }^{3}$ University of Florida, Gainesville, Florida, USA \\ ${ }^{4}$ Embrapa Maize and Sorghum, Brazilian Agricultural Research Corporation (Embrapa), Sete Lagoas, Minas Gerais, Brazil \\ ${ }^{5}$ Agronomic Institute of Pernambuco (IPA), Recife, Pernambuco, Brazil \\ ${ }^{6}$ Federal University of Sergipe, Aracaju, Sergipe, Brazil \\ ${ }^{7}$ Federal University of Minas Gerais, Belo Horizonte, Minas Gerais, Brazil
}

(Received 7 November 2014; revised 28 July 2015; accepted 21 August 2015;

first published online 14 October 2015)

\section{SUMMARY}

Pearl millet (Pennisetum glaucum (L.) R.) could play an important role as a feed source for ruminants in arid and semiarid zones of the world owing to its high yield and drought tolerance. The current paper assessed the agronomic characteristics, ensilability, intake and digestibility of five Brazilian pearl millet cultivars (IPA Bulk1BF, BRS 1501, CMS03, CMS-01 and BN-2) in a typical Brazilian northeastern semi-arid climate. Forage was harvested at the dough stage of grain maturity (growth stage 86 according to the $\mathrm{BBCH}$ scale) and ensiled under laboratory and farm conditions. Apparent digestibility of the silages was determined using 25 Santa Inês male lambs. The cultivars CMS-01, CMS-03 and $\mathrm{BN}-2$ out-performed the others in terms of dry matter (DM) and digestible DM yield/ha. At DM partitioning among plant tissues, the cultivar IPA Bulk1BF had a greater DM associated with panicles and one of the greatest concentrations of organic matter, lactic acid and in vitro dry matter digestibility among the five cultivars. The cultivar BRS 1501 had greater butyric acid concentration as well as one of the highest $\mathrm{pH}$ values. Silage produced from $\mathrm{BN}-2$ not only contained greater acetic acid concentration, but also showed one of the greatest total volatile fatty acid concentrations. There were no differences in feed intake and digestibility of nutrients and fibre fractions across all cultivars. Silage made from BN-2 resulted in greater urinary excretion of nitrogen than those produced from BRS 1501. Under the conditions of the present study, the results obtained for production of DM and digestible dry matter, and the ratio of plant fractions, indicates the possible use of these cultivars for silage production in the Brazilian semi-arid region.

\section{INTRODUCTION}

Climate change has been the principal source of fluctuations in global food production in arid and semiarid regions where extremes of heat and cold, together with drought and floods, have negatively impacted agriculture (Oseni \& Masarirambi 2011). Furthermore, social and political-economic factors have contributed to increased vulnerability, economic loss, hunger and dislocation (Sivakumar et al. 2005). Within this

\footnotetext{
* To whom all correspondence should be addressed. Email: rafael. dantas@embrapa.br
}

context, it is imperative to identify water-use efficient plants that can adapt to climate change and increase the use of rain-fed crops to achieve sustainable agricultural development in areas that are more prone to extreme weather (Lobell et al. 2008).

Pearl millet (Pennisetum glaucum (L.) R.) could be a key feed source in agricultural adaptation in dry regions as it is a tropical plant possessing the $\mathrm{C}_{4}$ photosynthetic pathway and tolerance to drought, heat and low soil pH (Maiti \& Wesche-Ebeling 1997). Because of its adaptability to harsh conditions, millet can be grown in areas that are unfavourable to other crops 
such as maize (Singh \& Singh 1995). Although several studies have evaluated the potential of pearl millet as silage for ruminants in dry regions (Messman et al. 1992; Hill et al. 1999), data on its nutritive value are limited.

The Brazilian Agricultural Research Corporation (EMBRAPA) has developed and released new varieties of pearl millet for field testing over the last 10 years, including the varieties BRS 1501, CMS-03 and CMS01, while the Agronomic Institute of Pernambuco (IPA) and Bonamigo Seeds have released the varieties IPA Bulk1BF and BN-2, respectively. In Brazil, smallscale trials were conducted to evaluate field performance of those five new cultivars, mainly in wet regions (Aguiar et al. 2006; Pires et al. 2007; Guimarães Júnior et al. 2009), and it was found that they could serve as a feed source for livestock during the dry season since they exhibited greater dry matter (DM) yield than members of the African and Indian germplasm banks, which are well adapted to semi-arid conditions (de Rouw 2004; Yadav \& Bidinger 2008; Bashir et al. 2014). Before recommending these new Brazilian cultivars for commercial use, other experiments should be carried out to investigate their agronomic and ensiling characteristics (i.e. DM partitioning among plant organs, in vitro dry matter digestibility (IVDMD), $\mathrm{pH}$, fermentation end products and chemical composition), as well as intake and in vivo digestibility, so that farmers and policy-makers have sufficient information about these new forages to address the food demands of livestock in semi-arid environments.

As a part of an overall strategy to deal with this issue, the present study evaluated agronomic characteristics of five new Brazilian cultivars of pearl millet (IPA Bulk1BF, BRS 1501, CMS-03, CMS-01 and BN2) and assessed their potential application in silage production. Finally, the impact of these new forages on intake and digestibility in lambs was quantified.

\section{MATERIALS AND METHODS}

Experiments location and general information

The experiment was conducted from July to October 2011 at the Semi-Arid Experimental Station of the Brazilian Agricultural Research Corporation (EMBRAPA) in the municipality of Nossa Senhora da

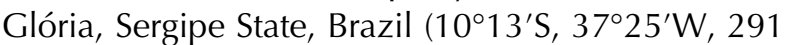
$\mathrm{m}$ a.s.I.). The soil type in this region is a eutrophic red-yellow podzol (dos Santos et al. 2013), with an average depth of $1.5 \mathrm{~m}$. The climate is typically semi-arid with annual rainfall of $710 \mathrm{~mm}$ and average maximum and minimum temperatures of 32 and $20{ }^{\circ} \mathrm{C}$, respectively. Precipitation in the region is low, erratic, and the balance between rainfall and evaporation rate can be negative in some months based on meteorological data from a weather station located about $400 \mathrm{~m}$ from the experimental site (Table 1). Seed of the five new pearl millet cultivars (IPA Bulk1BF, BRS 1501, CMS-03, CMS-01 and BN2) was supplied by the pearl millet breeding programmes of EMBRAPA, IPA and Bonamigo Seeds.

\section{Agronomic characteristics}

Treatments were the five cultivars replicated five times in a randomized complete block design (25 plots). Plots measured $10.5 \mathrm{~m}^{2}\left(5 \times 2.1 \mathrm{~m}^{2}\right)$, with plants seeded in four rows $(0.70 \mathrm{~m}$ centres) to a depth of 3 $\mathrm{cm}$. The soil at the site had the following properties: $\mathrm{pH}$ (water): $5 \cdot 8$; phosphorus (P): $2.8 \mathrm{mg} / \mathrm{dm}^{3}$; potassium (K): $0.32 \mathrm{cmol}_{\mathrm{C}} / \mathrm{dm}^{3}$; aluminium (Al): 0.05; hydrogen $(\mathrm{H})+\mathrm{Al}\left(\mathrm{cmol}_{\mathrm{C}} / \mathrm{dm}^{3}\right)$ : $1 \cdot 89$; calcium $(\mathrm{Ca})$ $\left(\mathrm{cmol}_{\mathrm{C}} / \mathrm{dm}^{3}\right): 1 \cdot 4$; magnesium $(\mathrm{Mg})\left(\mathrm{cmol}_{\mathrm{C}} / \mathrm{dm}^{3}\right): 0 \cdot 74$ and organic matter $(\mathrm{OM} ; \mathrm{g} / \mathrm{kg}): 10 \cdot 54$. All plots were randomly allocated and fertilized prior to planting according to soil test recommendations with $150 \mathrm{~kg}$ $\mathrm{N} / \mathrm{ha}, 300 \mathrm{~kg}$ P/ha and $250 \mathrm{~kg} \mathrm{~K} / \mathrm{ha}$. Two-side dressing fertilizations were applied, the first on the 25th day and the second on the 40th day after plant emergence, at a rate of $60 \mathrm{~kg} \mathrm{~N} / \mathrm{ha}$ in each side dressing. Each treatment comprised c. 32 plants $/ \mathrm{m}^{2}$, achieved by thinning plots 20 days after emergence. Five litres/ha of Atrazine [2-chloro-4-ethylamino-6-isopropylamino-striazine] $\left(\right.$ Atanor $^{\circledR}$, Porto Alegre, Rio Grande do Sul, Brazil) (concentration of active: $500 \mathrm{~g} / \mathrm{l}$ ) was applied on all plot areas for weed control immediately after planting.

Cultivars were harvested when a proportion of at least 0.60 of plants in each plot reached the dough stage of grain maturity (growth stage 86 according to the BBCH scale; $\mathrm{BBCH}$ 2001). Plants were harvested manually, cut at $5 \mathrm{~cm}$ above ground level. Only the two central rows in each plot were kept, collected into baskets and weighed to estimate wet yield/ha, with the remainder being discarded. After chopping a representative sample from each plot, a $400 \mathrm{~g}$ subsample was oven-dried at $55{ }^{\circ} \mathrm{C}$ for $48 \mathrm{~h}$ to estimate DM concentration and yield of the five cultivars. Dry samples were ground through a $1 \mathrm{~mm}$ screen using a Wiley Mill (Tecnal Ltd., São Paulo, São Paulo, Brazil) and stored at room temperature. 
Table 1. Meteorological data during the experimental period

\begin{tabular}{|c|c|c|c|c|c|c|c|c|}
\hline \multirow[b]{2}{*}{ Month/year } & \multirow[b]{2}{*}{ Days* } & \multirow[b]{2}{*}{ Rain (mm) } & \multicolumn{3}{|c|}{ Temperature $\left({ }^{\circ} \mathrm{C}\right)$} & \multirow[b]{2}{*}{ Evaporation (mm) } & \multirow[b]{2}{*}{ RH (fraction) } & \multirow[b]{2}{*}{ Wind $(\mathrm{km} /$ day $)+$} \\
\hline & & & Max. & Min. & Mean & & & \\
\hline Jun 2011 & 24 & 48 & 27 & 19 & 22 & 103 & $0 \cdot 69$ & 99 \\
\hline Jul 2011 & 22 & 112 & 26 & 18 & 21 & 81 & $0 \cdot 68$ & 100 \\
\hline Aug 2011 & 21 & 69 & 27 & 18 & 22 & 119 & $0 \cdot 66$ & 99 \\
\hline Sep 2011 & 14 & 46 & 28 & 18 & 22 & 115 & $0 \cdot 67$ & 108 \\
\hline Oct 2011 & 5 & 49 & 31 & 20 & 24 & 132 & $0 \cdot 70$ & 115 \\
\hline
\end{tabular}

Source: Agro meteorological station in the Experimental Area of Gloria, Embrapa Semi-Arid - Nossa Senhora da Glória Sergipe State, Brazil.

$\mathrm{RH}$, relative humidity (fraction).

* Rainfall occurrence in days.

+ Wind average speed at $2 \mathrm{~m}$ height.

The agronomic characteristics studied included: plant height, population density, extent of lodging, DM partitioning of plant organs (panicle, stem and leaf), DM yield (DMY) (t/ha) and digestible DM yield (DDMY) (t/ha). The height of ten randomly selected plants within each plot was determined by measuring from ground level to the top of the panicle using a tape measure. Plants were then separated into panicles, stems and leaves, with the mass of each fraction determined after oven-drying at $65^{\circ} \mathrm{C}$ for $72 \mathrm{~h}$. Lodging was estimated as the percentage area of plot that was lodged and the angle of stem lodging was estimated. An angle of $10^{\circ}$ from perpendicular was scored as 10 and prostrate stems were scored as 90 . A lodging score for the plot was then calculated as: (\% plot area lodged $\times$ angle of lodging from vertical)/90 as described by Bell \& Fischer (1994). The DDMY was estimated by multiplying the IVDMD (determined as described below) from each repetition by its respective DMY.

The water-use efficiency for DMY and DDMY, expressed in $\mathrm{kg} / \mathrm{ha} / \mathrm{mm}$, was estimated by dividing the yield by the amount of accumulated rainfall during the crop cycle $(229 \mathrm{~mm})$ as described by Devasenapathy et al. (2008).

Growing degree days (GDD) were used to calculate and express daily heat unit accumulation relative to the pearl millet crop using temperature data as described by Norman et al. (1995).

\section{Ensiling procedure}

At harvest, a silage harvester (Nogueira ${ }^{\circledR}$, São João da Boa Vista, São Paulo, Brazil) was used to chop plants within each treatment to an average of $1.5 \mathrm{~cm}$ long and transferred into $25 \times 250$-litre plastic barrels.
Representative herbage samples from each plot were packed manually into polyvinyl chloride minisilos (five mini-silos $\times$ five replications for a total of 25 mini-silos; $10.5 \mathrm{~cm}$ diameter $\times 35.5 \mathrm{~cm}$ high, capacity of $2.5 \mathrm{~kg}$ and average density of $813.7 \mathrm{~kg} / \mathrm{m}^{3}$ ) using a wooden pestle (Sebastian et al. 1996). The mini-silos were sealed with plastic lids, weighed and stored at room temperature.

Mini-silos were opened following 90 days of ensiling, with forage samples (15 g) from both mini-silos and plastic barrels being homogenized for $1 \mathrm{~min}$ in $500 \mathrm{ml}$ of distilled water to measure the $\mathrm{pH}$ using a pH meter (TEC- $5^{\circledR}$, Tecnal Ltd., São Paulo, São Paulo, Brazil). Aqueous extracts $(10 \mathrm{ml})$ were acidified with $50 \mu \mathrm{l}$ of $9.77 \mathrm{~mol} / \mathrm{l}$ of sulphuric acid $\left(\mathrm{H}_{2} \mathrm{SO}_{4}\right)$ (Kung \& Ranjit 2001) and frozen before analysis. Thawed extract samples were centrifuged for $15 \mathrm{~min}$ at $10000 \mathrm{~g}$ at $4{ }^{\circ} \mathrm{C}$ and analysed for acetic, propionic, lactic and butyric acids using a Varian high-performance liquid chromatography (HPLC) system (Merck Hitachi, Elite Lachrom HTA, Tokyo, Japan) as described by Adams et al. (1984). Organic acids were separated using an Aminex HPX-87H column $\left(300 \times 7.8 \mathrm{~mm}^{2}\right.$; Bio-Rad, Hercules, CA, USA $)$ with a mobile phase of $0.013 \mathrm{M} \mathrm{H}_{2} \mathrm{SO}_{4}$ at a flow rate of 0.5 $\mathrm{ml} / \mathrm{min}$. Organic acids were quantified using an ultraviolet detector (Merck Hitachi L-2400) set at $210 \mathrm{~nm}$.

Ammonia was determined using a phenolhypochlorite reaction, as described by Weatherburn (1967). Finally, silage sub-samples (500 g) were oven-dried at $60^{\circ} \mathrm{C}$ for $72 \mathrm{~h}$, ground through a $1 \mathrm{~mm}$ screen using a Wiley Mill (Tecnal Ltd., São Paulo, São Paulo, Brazil) and stored at room temperature until further analysis. 
Intake and digestibility measurements

All lambs were cared for in accordance with the guidelines of the Brazilian Council on Animal Care (CONCEA 2008). Apparent nutrient digestibility of silages was measured using 25 Santa Inês male lambs (initial body weight (BW): $19 \mathrm{~kg} \pm 1.6 \mathrm{~kg}$ ) over a 21-day period. Lambs were blocked by weight and assigned randomly to one of the five treatments. The first 17 days were used to adapt lambs to the diets in individual metabolic cages equipped with a polyethylene sieve tray to separate faeces from urine. Lambs were fed pearl millet silage only (without concentrate) twice daily at 07.30 and $16.30 \mathrm{~h}$ in a manner that assured $0 \cdot 15$ orts at the morning feeding. Water and a trace mineralized salt mixture were available to lambs ad libitum.

Apparent digestibility was determined over 5 days, with lambs being fed pearl millet silage ad libitum as described by da Silva \& Leão (1979). During these 5 days, total faeces, feed and orts of each lamb were measured and sampled daily. Samples of the 5 days were mixed, sub-sampled (400 g fresh faeces, $400 \mathrm{~g}$ fresh feeds and $400 \mathrm{~g}$ fresh orts per lamb) and stored at $-20{ }^{\circ} \mathrm{C}$ until analysed. The total urine output of each animal was collected daily into plastic containers containing $100 \mathrm{ml}$ of hydrochloric acid (HCL) with $2 \mathrm{~N}$ concentration to prevent fermentation, degradation and nitrogen $(\mathrm{N})$ losses. During the 5-day collection phase, sub-samples $(10 \%$ from the total urine volume) were collected in the morning and stored at $-20{ }^{\circ} \mathrm{C}$ until further analysis.

\section{Chemical analysis}

Ground samples were analysed for DM and OM as described by AOAC (2005) (methods 942.05 and 934.01). A Leco combustion $\mathrm{N}$ analyser (FP-428N Determinator, Leco Corporation, St Joseph, MI, USA) was used to measure $\mathrm{N}$ concentration. Crude protein (CP) was calculated as $N \times 6 \cdot 25$. Both neutral detergent fibre (NDF), which was determined by using heat stable $\alpha$-amylase, and sodium sulphite (ash free) and acid detergent fibre (ADF) were quantified using an Ankom Fibre Analyser (Ankom Technology Corporation, Macedon, NY, USA) as described by Van Soest et al. (1991). The concentration of hemicellulose was determined by subtracting ADF from NDF. Ether extract (EE) was determined as described by AOAC (2005) (method 920.39) using an Ankom Fat Extractor (Ankom Technology Corporation, Macedon, NY, USA).
Gross energy was determined using an adiabatic calorimeter (model 1241; Parr, Moline, IL, USA). Non-fibrous (NFC) carbohydrates were calculated

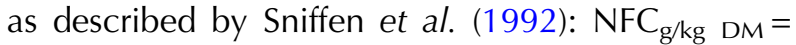
$100-(\mathrm{CP}+\mathrm{EE}+\mathrm{ash}+\mathrm{NDF})$. The concentrations of total digestible nutrients $(\mathrm{TDN})$ were calculated as: $\mathrm{TDN}_{\mathrm{g} / \mathrm{kg} \text { DM }}=$ digestible $\mathrm{CP}+(2 \cdot 25 \times$ digestible EE $)+$ digestible NDF + digestible NFC (Weiss \& Wyatt 2000).

In vitro $\mathrm{DMD}$ analysis of fresh forage and silage was conducted in $100 \mathrm{ml}$ serum bottles and examined in a single run for each forage/silage with triplicate bottles being used per treatment. Plant material $(0.5 \mathrm{~g})$ was incubated with $10 \mathrm{ml}$ of rumen fluid mixed with 40 $\mathrm{ml}$ of McDougall's buffer (McDougall 1948) for $48 \mathrm{~h}$ at $39^{\circ} \mathrm{C}$. Samples were subsequently incubated with $0 \cdot 1 \mathrm{~N} \mathrm{HCL}$ and $2 \mathrm{~g} / \mathrm{l}$ pepsin for a further $48 \mathrm{~h}$ (Tilley \& Terry 1963). Equal volumes of rumen fluid were collected immediately after feeding from three rumen-fistulated bulls fed a mixture of the five pearl millet cultivars. After stirring the three samples, the combined ruminal fluid was used in the IVDMD assay as described above.

\section{Statistical methods}

Experiments were analysed using a mixed model approach with cultivar as a fixed effect, random effects of blocks (agronomic and silage quality trials) and lambs (digestibility study), and random residual error using the MIXED procedure of SAS Version 9.1 statistical program (SAS 2002). When significant, cultivar means were compared using Fisher's protected LSD (i.e., the DIFF option of the LSMEANS statement). Significance was declared at $P<0 \cdot 05$.

\section{RESULTS}

\section{Agronomic characteristics}

Cultivar height at harvest ranged from 146 to $200 \mathrm{~cm}$, with CMS-01 being $43 \%$ taller $(P<0 \cdot 05)$ than BRS 1501, although no difference was observed between CMS-01 and BN-2. At the same plant density, BN-2, CMS-01 and CMS-03 yielded more $(P<0.05)$ DM and digestible DM than BRS 1501, which was similar to IPA Bulk1BF.

The cultivar IPA Bulk1BF exhibited the highest $(P<0.05)$ proportion of panicles, although there was similarity in DM partitioning of panicles for CMS-03 and $\mathrm{BN}-2$. As for lodging, CMS-03 exhibited more 
$(P<0 \cdot 05)$ resilient stems than BRS 1501 and IPA Bulk1BF, but no difference was observed among CMS-03, CMS-01 and BN-2 (Table 2).

\section{Silage quality}

After ensiling, DM concentration of the cultivars ranged from 340 to $371 \mathrm{~g} / \mathrm{kg}$ and did not differ among treatments. Organic matter concentration ranged from 927 to $939 \mathrm{~g} / \mathrm{kg}$ and was greater $(P<$ 0.05) in CMS-01 than BRS 1501 silage. Silages produced from IPA Bulk1BF, CMS-01 and CMS-03 had greater $(P<0 \cdot 05)$ IVDMD than BRS 1501 silages.

A larger variation in fermentation products was detected among treatments, with CMS-03 and IPA Bulk1BF silages having the lowest $(P<0 \cdot 05) \mathrm{pH}$, although they did not differ significantly from CMS-01. Acetic acid concentration was greater $(P<0.05)$ in silages produced from $\mathrm{BN}-2$ compared with the other cultivars. However, concentrations of total volatile fatty acids (VFA) in ensiled BN-2 were greater $(P<$ $0 \cdot 05)$ than those from CMS-03, although there were no differences among BRS 1501, CMS-01 and IPA Bulk1BF. Concentrations of lactic acid in silages produced from IPA Bulk1BF and CMS-03 were greater $(P<0.05)$ than in $\mathrm{BN}-2$. Finally, concentrations of butyric acid in silages obtained from BRS 1501 were greater $(P<0.05)$ than those observed for $\mathrm{BN}-2$ (Table 3).

\section{Digestion study}

Intake and digestibility were not affected by cultivar (Table 4); however, BRS 1501 resulted in a lower $(P<0 \cdot 05)$ urinary $\mathrm{N}$ excretion than $\mathrm{BN}-2$ (Table 5).

\section{DISCUSSION}

Several studies have indicated that pearl millet is an excellent feed for livestock in arid regions owing to its desirable characteristics for ensiling and potential to yield high biomass in these regions (ICRISAT 2009; Kholova et al. 2010).

The mean $( \pm$ S.D.) whole-crop DMY of $14( \pm 3 \cdot 9)$ t/ha in the present study was greater than the range of values reported for three African genotypes (7-8 t/ha) and two Brazilian cultivars ( $7 \mathrm{t} / \mathrm{ha}$ ) of pearl millet grown in the Brazilian sub-tropical climate (Costa et al. 2005). It is possible that greater daily heat unit accumulation observed during the growing season in Northeast Brazil (1648 growing degree days
(GDD) $-{ }^{\circ} \mathrm{C}$ ) compared with those in Southwest Brazil (Costa et al. 2005) (1204 GDD $-{ }^{\circ} \mathrm{C}$ ) may explain the differences in DMY, as the cultivars from both experimental sites were cultivated in a soil with similar characteristics and harvested at almost the same whole plant moisture. Among the cultivars in the present study, CMS-03, CMS-01 and BN-2 had greater DMY than BRS 1501 and IPA Bulk1BF likely because they had greater plant height and were more resistant to lodging (Akromah et al. 2008; Silungwe et al. 2010).

The Brazilian pearl millets evaluated exhibited lower IVDMD than that described for conventional and brown midrib (BMR) pearl millet grown in Canada (Hassanat et al. 2006; Amer et al. 2012), possibly because of a greater concentration of ADF exhibited in the Brazilian cultivars.

In general, the fermentation profile observed in Brazilian pearl millet silages was within the limits recommended by McDonald et al. (1991) and Tomich et al. (2003). These findings also suggest that enterobacteria and clostridia had little activity in the ensiled material, as these microorganisms have limited growth rate in silage exhibiting $>280 \mathrm{~g} / \mathrm{kg}$ $\mathrm{DM}$ and $\mathrm{pH}<4$ (McDonald et al. 1991). Although butyric acid was detected in silage evaluated in the current work, its concentration was low $(0 \cdot 6 \pm 0 \cdot 13)$, suggesting that clostridial activity was minimal (Ward et al. 2001). Lower concentration of lactic acid and higher concentration of acetic acid in $\mathrm{BN}-2$ silage as compared with the other treatments may have resulted from heterolactic and/or enterobacterial fermentation (McDonald et al. 1991), although those concentrations were not sufficient to cause DM and energy losses or to reduce gross energy intake in animals fed $\mathrm{BN}-2$.

Intake of DM, OM and $\mathrm{CP}$ were similar to the results obtained by Amodu et al. (2008). They observed intake ( \pm S.E.M.) of $365( \pm 12 \cdot 4), 319( \pm 20 \cdot 1)$ and 18 $( \pm 5 \cdot 3) \mathrm{g}$ /day for DM, OM and CP, respectively, for pearl millet fed Yankasa lambs reared in Nigeria.

The similarity in concentrations of fibre fractions in silage generated from the current work as compared with other trials carried out around the world resulted in almost the same consumption of NDF and ADF as described by Khan et al. (2011), who reported intake of $586 \mathrm{~g}( \pm 17 \cdot 1) \mathrm{NDF} /$ day in animals weighing 30 $\mathrm{kg} \pm 4 \cdot 45$. The average NDF intake as a percentage of BW $(2 \cdot 8 \%)$ was higher than that shown by dos Santos et al. (2011), who reported a percentage of $1.5 \%$ for Santa Ines lambs reared in the Brazilian semi-arid zone and fed maize silage. 
Table 2. Performance and phenological traits of pearl millet cultivars

\begin{tabular}{|c|c|c|c|c|c|c|c|c|}
\hline Variable & $\begin{array}{l}\text { IPA } \\
\text { Bulk1BF }\end{array}$ & $\begin{array}{l}\text { BRS } \\
1501\end{array}$ & $\begin{array}{l}\text { CMS- } \\
03\end{array}$ & $\begin{array}{l}\text { CMS- } \\
01\end{array}$ & $\begin{array}{l}\mathrm{BN}- \\
2\end{array}$ & Mean & S.E.M. & $P$ \\
\hline Plant height $(\mathrm{cm})$ & 171 & 146 & 183 & 200 & 199 & 179 & $5 \cdot 0$ & $<0 \cdot 01$ \\
\hline Plant density (1000 plants/ha) & 343 & 307 & 345 & 299 & 349 & 329 & $15 \cdot 2$ & $0 \cdot 064$ \\
\hline Dry matter yield (t/ha) & $10 \cdot 3$ & $8 \cdot 4$ & $16 \cdot 3$ & $16 \cdot 2$ & $16 \cdot 2$ & $13 \cdot 5$ & $1 \cdot 85$ & $<0 \cdot 001$ \\
\hline Digestible dry matter yield (t/ha) & $5 \cdot 2$ & $3 \cdot 3$ & $8 \cdot 2$ & $8 \cdot 1$ & $8 \cdot 1$ & $6 \cdot 6$ & $0 \cdot 86$ & $<0 \cdot 001$ \\
\hline Lodging score & $1 \cdot 5$ & $1 \cdot 5$ & $0 \cdot 6$ & $1 \cdot 1$ & $1 \cdot 0$ & $1 \cdot 1$ & $0 \cdot 12$ & $<0 \cdot 001$ \\
\hline \multicolumn{9}{|l|}{$\begin{array}{l}\text { DM partitioning of plant organs } \\
\text { (proportion) }\end{array}$} \\
\hline Panicles & $0 \cdot 54$ & 0.43 & $0 \cdot 53$ & $0 \cdot 45$ & $0 \cdot 46$ & $0 \cdot 48$ & $0 \cdot 026$ & $0 \cdot 046$ \\
\hline Stems & $0 \cdot 35$ & $0 \cdot 42$ & $0 \cdot 35$ & $0 \cdot 42$ & $0 \cdot 40$ & $0 \cdot 38$ & 0.023 & $0 \cdot 205$ \\
\hline Leaves & $0 \cdot 11$ & $0 \cdot 15$ & $0 \cdot 12$ & $0 \cdot 13$ & $0 \cdot 14$ & $0 \cdot 13$ & $0 \cdot 010$ & $0 \cdot 262$ \\
\hline
\end{tabular}

DM, dry matter; S.E.M., standard error of mean; $P$, probability (if treatments differ at $P<0 \cdot 05$ ); D.F., 16.

Table 3. Chemical composition ( $\mathrm{g} / \mathrm{kg} D \mathrm{DM})$ and fermentation product concentrations $(\mathrm{g} / \mathrm{kg} \mathrm{DM})$ of silages produced from pearl millet cultivars

\begin{tabular}{|c|c|c|c|c|c|c|c|c|}
\hline Variable & $\begin{array}{l}\text { IPA } \\
\text { Bulk1BF }\end{array}$ & $\begin{array}{l}\text { BRS } \\
1501\end{array}$ & $\begin{array}{l}\text { CMS- } \\
03\end{array}$ & $\begin{array}{l}\text { CMS- } \\
01\end{array}$ & $\begin{array}{l}\mathrm{BN}- \\
2\end{array}$ & Mean & S.E.M. & $P$ \\
\hline DM (g/kg) & 340 & 341 & 350 & 350 & 371 & 350 & $9 \cdot 8$ & $0 \cdot 100$ \\
\hline $\mathrm{pH}$ & $3 \cdot 8$ & $3 \cdot 9$ & $3 \cdot 8$ & $3 \cdot 8$ & $3 \cdot 9$ & $3 \cdot 9$ & $0 \cdot 02$ & $0 \cdot 003$ \\
\hline GE (MJ/kg DM) & $16 \cdot 5$ & $16 \cdot 4$ & $16 \cdot 3$ & $16 \cdot 4$ & $16 \cdot 1$ & $16 \cdot 3$ & $0 \cdot 38$ & $0 \cdot 906$ \\
\hline \multicolumn{9}{|c|}{$\begin{array}{l}\text { Chemical composition and fermentation product } \\
\text { concentrations (g/kg DM) }\end{array}$} \\
\hline Crude protein & 102 & 106 & 112 & 112 & 109 & 108 & $0 \cdot 4$ & $0 \cdot 331$ \\
\hline NDF & 523 & 567 & 528 & 554 & 577 & 550 & $1 \cdot 8$ & $0 \cdot 135$ \\
\hline ADF & 329 & 348 & 337 & 341 & 353 & 342 & $1 \cdot 3$ & $0 \cdot 117$ \\
\hline Hemicellulose & 224 & 219 & 191 & 213 & 194 & 208 & $0 \cdot 7$ & $0 \cdot 307$ \\
\hline Non-fibrous carbohydrate & 311 & 268 & 305 & 287 & 266 & 288 & $1 \cdot 7$ & $0 \cdot 174$ \\
\hline Organic matter & 930 & 927 & 938 & 939 & 937 & 934 & $0 \cdot 3$ & $0 \cdot 015$ \\
\hline Ether Extract & 33 & 34 & 42 & 34 & 42 & 37 & $0 \cdot 3$ & $0 \cdot 074$ \\
\hline IVDMD (proportion of DM) & $0 \cdot 51$ & $0 \cdot 43$ & $0 \cdot 48$ & $0 \cdot 50$ & $0 \cdot 48$ & $0 \cdot 48$ & $0 \cdot 012$ & $0 \cdot 009$ \\
\hline Acetic acid & $14 \cdot 5$ & $14 \cdot 4$ & $11 \cdot 3$ & $12 \cdot 2$ & $16 \cdot 3$ & $13 \cdot 7$ & $0 \cdot 47$ & $<0 \cdot 001$ \\
\hline Propionic acid & $3 \cdot 2$ & $2 \cdot 8$ & $2 \cdot 3$ & $3 \cdot 9$ & $3 \cdot 6$ & $3 \cdot 1$ & $0 \cdot 55$ & $0 \cdot 112$ \\
\hline Butyric acid & $0 \cdot 51$ & $0 \cdot 71$ & $0 \cdot 56$ & $0 \cdot 57$ & $0 \cdot 44$ & $0 \cdot 56$ & $0 \cdot 025$ & $<0 \cdot 001$ \\
\hline Total VFA & $18 \cdot 2$ & $17 \cdot 9$ & $14 \cdot 1$ & $16 \cdot 6$ & $20 \cdot 3$ & $17 \cdot 4$ & $1 \cdot 01$ & $0 \cdot 002$ \\
\hline $\mathrm{NH}_{3}-\mathrm{N} / \mathrm{TN}$ & 44 & 48 & 44 & 47 & 52 & 47 & $2 \cdot 7$ & $0 \cdot 251$ \\
\hline Lactic acid & 69 & 63 & 65 & 58 & 55 & 62 & $2 \cdot 4$ & $0 \cdot 001$ \\
\hline
\end{tabular}

DM, dry matter; NDF, neutral detergent fibre; ADF, acid detergent fibre; IVDMD, in vitro dry matter digestibility; VFA, acetic acid + propionic acid + butyric acid; TN, total nitrogen; GE, gross energy; MJ, Megajoule; s.E.M., standard error of mean; $P$, probability (if treatments differ at $P<0 \cdot 05$ ); D.F., 16 .

The digestion study revealed that the mean apparent digestibility of DM $(0 \cdot 49 \pm 0 \cdot 089)$ and NDF $(0.43 \pm 0.096)$ of the Brazilian northeastern pearl millets were quite similar to those reported for pearl millet cultivated in temperate climates (for instance, Ward et al. 2001 obtained values of 0.51 and 0.50 for DM and NDF digestibilities, respectively).
On average, the CP concentration of Brazilian pearl millets (mean \pm S.E.M.; $108 \pm 0 \cdot 8 \mathrm{~g} / \mathrm{kg}$ DM) was similar to other cultivars grown at various locations. For example, Hassanat et al. (2006) reported conventional pearl millet with a CP concentration of $98( \pm 0 \cdot 9) \mathrm{g} / \mathrm{kg}$ DM and $107( \pm 0.9) \mathrm{g} / \mathrm{kg}$ DM for BMR pearl millet. The ratio of $\mathrm{N}$ intake to $\mathrm{N}$ absorbed in the present study 
Table 4. Dry matter intake ( $\mathrm{g} / \mathrm{kg}$ )and total apparent digestibility (fraction) of dietary components in lambs fed silage produced from five pearl millet cultivars

\begin{tabular}{|c|c|c|c|c|c|c|c|c|}
\hline Variable & IPA Bulk1BF & BRS 1501 & CMS-03 & CMS-01 & $\mathrm{BN}-2$ & Mean & S.E.M. & $P$ \\
\hline \multicolumn{9}{|l|}{ Intake (g/day) } \\
\hline Dry matter & 421 & 426 & 463 & 459 & 413 & 436 & $76 \cdot 2$ & $0 \cdot 983$ \\
\hline Organic matter & 394 & 378 & 438 & 430 & 373 & 403 & $68 \cdot 9$ & $0 \cdot 940$ \\
\hline Crude protein & 53 & 46 & 58 & 47 & 44 & 50 & $8 \cdot 1$ & $0 \cdot 760$ \\
\hline NDF & 247 & 218 & 260 & 292 & 242 & 252 & $44 \cdot 5$ & $0 \cdot 830$ \\
\hline ADF & 113 & 103 & 114 & 144 & 113 & 118 & $21 \cdot 2$ & $0 \cdot 711$ \\
\hline Non-fibrous carbohydrates & 87 & 105 & 111 & 86 & 76 & 92 & $15 \cdot 5$ & $0 \cdot 465$ \\
\hline Ether extract & 8 & 8 & 11 & 7 & 9 & 9 & $1 \cdot 5$ & $0 \cdot 594$ \\
\hline TDN & 316 & 305 & 342 & 328 & 293 & 317 & $35 \cdot 4$ & $0 \cdot 877$ \\
\hline GE (MJ/day) & 7 & 8 & 8 & 8 & 7 & 8 & $1 \cdot 3$ & $0 \cdot 990$ \\
\hline \multicolumn{9}{|c|}{ Total apparent digestibility (fraction) } \\
\hline Dry matter & $0 \cdot 51$ & $0 \cdot 48$ & $0 \cdot 48$ & $0 \cdot 50$ & $0 \cdot 49$ & $0 \cdot 49$ & $0 \cdot 043$ & $0 \cdot 990$ \\
\hline Organic matter & $0 \cdot 55$ & $0 \cdot 50$ & $0 \cdot 53$ & $0 \cdot 55$ & $0 \cdot 52$ & $0 \cdot 53$ & $0 \cdot 042$ & $0 \cdot 863$ \\
\hline Crude protein & $0 \cdot 51$ & $0 \cdot 53$ & $0 \cdot 54$ & $0 \cdot 54$ & $0 \cdot 51$ & $0 \cdot 53$ & $0 \cdot 042$ & 0.975 \\
\hline NDF & $0 \cdot 47$ & $0 \cdot 39$ & $0 \cdot 42$ & $0 \cdot 45$ & $0 \cdot 41$ & $0 \cdot 43$ & $0 \cdot 044$ & $0 \cdot 683$ \\
\hline ADF & $0 \cdot 40$ & $0 \cdot 35$ & $0 \cdot 31$ & $0 \cdot 42$ & $0 \cdot 36$ & $0 \cdot 37$ & $0 \cdot 055$ & $0 \cdot 597$ \\
\hline Non-fibrous carbohydrates & $0 \cdot 76$ & $0 \cdot 82$ & $0 \cdot 83$ & $0 \cdot 75$ & $0 \cdot 79$ & $0 \cdot 79$ & $0 \cdot 045$ & $0 \cdot 589$ \\
\hline Ether extract & $0 \cdot 40$ & $0 \cdot 41$ & $0 \cdot 38$ & $0 \cdot 39$ & $0 \cdot 43$ & $0 \cdot 40$ & $0 \cdot 066$ & $0 \cdot 989$ \\
\hline
\end{tabular}

NDF, neutral detergent fibre; ADF, acid detergent fibre; TDN, total digestible nutrients; GE, gross energy; MJ, Megajoule; S.E.M., standard error of mean; $P$, probability (if treatments differ at $P<0 \cdot 05$ ); D.F., 16.

Table 5. Nitrogen balance in lambs fed silage of five pearl millet cultivars

\begin{tabular}{lllllllll}
\hline \hline Variable & IPA Bulk1BF & BRS 1501 & CMS-03 & CMS-01 & BN-2 & Mean & S.E.M. & $P$ \\
\hline $\mathrm{N}$ intake (g/day) & $8 \cdot 5$ & $7 \cdot 4$ & $9 \cdot 2$ & $7 \cdot 5$ & $7 \cdot 1$ & $8 \cdot 0$ & $1 \cdot 29$ & $0 \cdot 749$ \\
$\mathrm{~N}$ faecal (g/day) & $3 \cdot 9$ & $3 \cdot 2$ & $4 \cdot 1$ & $3 \cdot 4$ & $3 \cdot 4$ & $3 \cdot 6$ & $0 \cdot 64$ & $0 \cdot 867$ \\
$\mathrm{~N}$ urinary (g/day) & $0 \cdot 5$ & $0 \cdot 3$ & $0 \cdot 5$ & $0 \cdot 7$ & $0 \cdot 8$ & $0 \cdot 5$ & $0 \cdot 08$ & $0 \cdot 002$ \\
$\mathrm{~N}$ absorbed (g/day) & $4 \cdot 1$ & $3 \cdot 9$ & $4 \cdot 6$ & $3 \cdot 4$ & $2 \cdot 9$ & $3 \cdot 8$ & $0 \cdot 81$ & $0 \cdot 652$ \\
$\mathrm{~N}$ absorbed/N intake & $0 \cdot 45$ & $0 \cdot 52$ & $0 \cdot 50$ & $0 \cdot 44$ & $0 \cdot 45$ & $0 \cdot 47$ & $0 \cdot 057$ & $0 \cdot 550$ \\
\hline \hline
\end{tabular}

N, nitrogen; S.E.M., standard error of mean; $P$, probability (if treatments differ at $P<0 \cdot 05$ ); D.F., 16.

was similar to that observed in Sipli lambs $(0 \cdot 51)$ fed pearl millet cultivars grown in semi-arid zones in Pakistan as evidenced by Khan et al. (2011). It should be mentioned that the positive $\mathrm{N}$ balance and lack of body reserve mobilization observed in all the lambs fed on the Brazilian pearl millet cultivars suggests an adequate digestibility of dietary protein.

Under the conditions of the present study, the Brazilian pearl millet cultivars could play a strategic role in further intensifying Brazilian grazing livestock systems in a sustainable way, mainly because these forages require less water to yield DM and digestible DM/ha than other feed sources (such as maize or sorghum) that could be planted in these regions. Indeed, the Brazilian pearl millet cultivars were more water-use efficient than sorghum and maize grown in semi-arid regions of Brazil $(56 \pm 2 \cdot 8 \mathrm{~kg}$ $\mathrm{DM} / \mathrm{ha} / \mathrm{mm}$ water for the Brazilian pearl millet cultivars v. $45 \pm 1.9 \mathrm{~kg} \mathrm{DM} / \mathrm{ha} / \mathrm{mm}$ water for sorghum; da Silva et al. 2011; and $21 \pm 2.4 \mathrm{~kg} \mathrm{DM} / \mathrm{ha} / \mathrm{mm}$ water for the Brazilian maize cultivars; dos Santos et al. 2010). The same response has been reported in temperate climate for maize $(11 \pm 2.5 \mathrm{~kg} \mathrm{DM} / \mathrm{ha} / \mathrm{mm})$ grown in the USA and sorghum (14 $\pm 1.4 \mathrm{~kg} \mathrm{DM} / \mathrm{ha} /$ $\mathrm{mm}$ ) planted in China that exhibited lower water-use efficiency than the Brazilian pearl millet cultivars (Deng et al. 2006; Nielsen et al. 2006).

Therefore, the present study showed that the Brazilian pearl millet cultivars have potential to yield forage with less water and on the same area of land 
in a Brazilian semi-arid area or in regions where irrigation is not possible and precipitation limits maize silage production. The cultivars CMS-03, CMS-01 and $\mathrm{BN}-2$ exhibited higher DMY per ha as compared with BRS 1501 and IPA Bulk1BF. It should be pointed out that differences in silage chemical composition among cultivars did not influence voluntary feed intake and apparent digestibility of nutrients in lambs. Finally, under the conditions of the present study, the results obtained for production of dry and digestible dry matter, and the ratio of plant fractions indicates the possible use of these cultivars on silage production in semi-arid regions of Brazil.

\section{REFERENCES}

Adams, R. F., Jones, R. L. \& Conway, P. L. (1984). Highperformance liquid-chromatography of microbial-acid metabolites. Journal of Chromatography B: Biomedical Sciences and Applications 336, 125-137.

Aguiar, E. A., Lima, E. F. C., Santos, M. V. F., Carvalho, F. F. R., Guim, A., Medeiros, H. R. \& Borges, A. Q. (2006). Yield and chemical composition of chopped tropical grass hays. Revista Brasileira de Zootecnia 35, 2226-2233.

Aкromah, R., Afribeh, D. \& Abdulal, M. S. (2008). Genetic variation and trait correlations in a bird-resistant pearl millet landrace population. African Journal of Biotechnology 7, 1847-1850.

Amer, S., Hassanat, F., Berthiaume, R., Seguin, P. \& MustafA, A. F. (2012). Effects of water soluble carbohydrate content on ensiling characteristics, chemical composition and in vitro gas production of forage millet and forage sorghum silages. Animal Feed Science and Technology 177, 23-29.

Amodu, J. T., Kallah, M.S., Adeyinka, I. A., Alawa, J.P. \& LAKPINI, C. A. M. (2008). The nutritive value of silages made from mixtures of pearl millet (Pennisetum americanum) and lablab (Lablab purpureus) as feed for Yankasa rams. Asian Journal of Animal and Veterinary Advances 3, 78-84.

AOAC (Association of Official Analytical Chemists) (2005). Official Methods of Analysis. 18th edn, methods 920.39, 942·05, 934·01, Arlington, VA: AOAC.

Bashir, E.M.A., Alı, A.M., Alı, A.M., Melchinger, A. E., Parzies, H.K. \& HaussmanN, B.I.G. (2014). Characterization of Sudanese pearl millet germplasm for agro-morphological traits and grain nutritional values. Plant Genetic Resources 12, 35-47.

$\mathrm{BBCH}$ (Biologische Bundesanstallt für Land-und Forstwirtschaft) (2001). Growth Stages of Mono-and Dicotyledonous Plants: BBCH Monograph. Berlin: Blackwell Wissenschafts-Verlag.

Bell, M.A. \& Fischer, R. A. (1994). Guide to Plant and Crop Sampling: Measurements and Observations for Agronomic and Physiological Research in Small Grain Cereals. Wheat Special Report no. 32. Mexico, DF: CIMMYT.
CONCEA (National Council for the Control of Animal Experimentation) (2008). Procedures for The Scientific Use of Animals. Based on the CLAUSE VII of the 1st Paragraph in Article 225 of the Brazilian Federal Constitution. Brasília, DF, Brazil: Brazilian Government through the National Council for the Control of Animal Experimentation (CONCEA) and Institutional Animal Care and Use Committees (CEUA).

Costa, A. C. T., Geraldo, J., Pereira, M. B. \& Pimentel, C. (2005). Thermal unities and yield of pearl millet genotypes sown in two seasons. Pesquisa Agropecuária Brasileira 40, 1171-1177.

DA Silva, J. F. C. \& Leão, M. I. (1979). Fundamentos de Nutrição dos Ruminantes. Piracicaba, SP, Brazil: Livroceres.

da Silva, T. C., Santos, E. M., Azevedo, J. A. G., Edvan, R. L., Perazzo, A. F., Pinho, R. M. A., Rodrigues, J. A.S. \& da Silva, D. S. (2011). Agronomic divergence of sorghum hybrids for silage yield in the semiarid region of Paraiba. Revista Brasileira de Zootecnia 40, 1886-1893.

Deng, X.P., Shan, L., Zhang, H. \& Turner, N. C. (2006). Improving agricultural water use efficiency in arid and semiarid areas of China. Agricultural Water Management 80, 23-40.

DE Rouw, A. (2004). Improving yields and reducing risks in pearl millet farming in the African Sahel. Agricultural Systems 81, 73-93.

Devasenapathy, P., Ramesh, T. \& Gangwar, B. (2008). Efficiency Indices for Agriculture Management Research. New Delhi, India: New India Publishing Agency.

dos Santos, H. G., Jacomine, P. K. T., dos Anjos, L. H. C., DE Oliveira, V. A., Lumbreras, J. F., Coelho, M. R., Almeida, J. A., Cunha, T.J.F. \& De Oliveira, J. B. (2013). Sistema Brasileiro de Classificação de Solos. Brasília, DF, Brazil: Embrapa.

dos Santos, R. D., Pereira, L. G. R., Neves, A. L. A., Azevedo, J. A. G., de Moraes, S. A. \& Costa, C. T. F. (2010). Agronomic characteristics of maize varieties for silage production in the submédio São Francisco river valley. Acta Scientiarum. Animal Sciences 32, 367-373.

dos Santos, R. D., Pereira, L. G. R., Neves, A. L. A., de Araujo, G. G. L., de Aragao, A. S. L. \& Chizzotti, M. L. (2011). Intake and total apparent digestibility in lambs fed six maize of maize varieties in the Brazilian Semi-arid. Revista Brasileira de Zootecnia 40, 29222928.

Guimarães Júnior, R., Gonçalves, L. C., Rodrigues, J. A. S., Pires, D. A. A., Jayme, D. G., Rodriguez, N. M. \& Saliba, E. O. S. (2009). Agronomic evaluation of pearl millet genotypes (P. Glaucum) planted in summer/fall growing season. Archivos de Zootecnia 58, 629-632.

Hassanat, F., Mustafa, A. F. \& Seguin, P. (2006). Chemical composition and ensiling characteristics of normal and brown midrib pearl millet harvested at two stages of development in southwestern Québec. Canadian Journal of Animal Science 86, 71-80.

Hill, G. M., Utley, P. R., Gates, R. N., Hanna, W. W. \& JoHnson, J. C. (1999). Pearl millet silage for growing beef heifers and steers. Journal of Production Agriculture 12, 653-658. 
ICRISAT (2009). Food Security and Diversification in the Drylands. Annual Report 2009. Patancheru, India: ICRISAT.

Khan, S. H., Shahzad, M. A., Nisa, M. \& Sarwar, M. (2011). Nutrients intake, digestibility, nitrogen balance and growth performance of sheep fed different silages with or without concentrate. Tropical Animal Health and Production 43, 795-801.

Kholova, J., Hash, C.T., Kumar, P.L., Yadav, R.S., Kocova, M. \& VAdEZ, V. (2010). Terminal drought-tolerant pearl millet (Pennisetum glaucum (L.) R. Br.) have high leaf $A B A$ and limit transpiration at high vapour pressure deficit. Journal of Experimental Botany 61, 1431-1440.

KUNG, L. \& RANIIT, N. K. (2001). The effect of Lactobacillus buchneri and other additives on the fermentation and aerobic stability of barley silage. Journal of Dairy Science 84, 1149-1155.

Lobell, D. B., Burke, M. B., Tebaldi, C., Mastrandrea, M. D., FALCON, W. P. \& NAYLOR, R. L. (2008). Prioritizing climate change adaptation needs for food security in 2030. Science 319, 607-610.

Maiti, R. \& Wesche-Ebeling, P. (1997). Pearl Millet Science. Enfield: Science Publishers Inc.

McDonald, P., Henderson, A. R. \& Heron, S. J. E. (1991). The Biochemistry of Silage. Kingston, Kent, UK: Chalcombe Publications.

McDougall, E. I. (1948). Studies on ruminant saliva. 1. The composition and output of sheep's saliva. Biochemical Journal 43, 99-109.

Messman, M.A., Weiss, W.P., Henderlong, P.R. \& SHOCKEY, W.L. (1992). Evaluation of pearl millet and field peas plus triticale silages for midlactation dairy cows. Journal of Dairy Science 75, 2769-2776.

Nielsen, D. C., Vigil, M. F. \& Benjamin, J. G. (2006). Forage yield response to water use for dryland corn, millet, and triticale in the Central Great Plains. Agronomy Journal 98, 992-998.

Norman, M. J. T., Pearson, C. J. \& Searle, P. G. E. (1995). Pearl millet (Pennisetum glaucum). In The Ecology of Tropical Food Crops, 2nd edn (Eds M. J. T. Norman, C. J. Pearson \& P. G. E. Searle), pp. 164-184. Cambridge, UK: Cambridge University Press.

Oseni, T. O. \& Masarirambi, M. T. (2011). Effect of climate change on maize (Zea mays) production and food security in Swaziland. American-Eurasian Journal Agricultural and Environmental Sciences 11, 385-391.

PiRes, F. R., de Assis, R. L., Silva, G.P., Braz, A. J. B.P., Santos, S. C., Vieira Neto, S. A. \& de Sousa, J. P. G. (2007). Desempenho agronômico de variedades de milheto em razão da fenologia em pré-safra (Agronomic acting of cultivars of pearl millet in reason of the fenology in precropping). Bioscience Journal 23, 41-49. (In Portuguese).

SAS (2002). SAS User's Guide, $9 \cdot 1$ edn. Cary, NC: SAS Institute Inc.
Sebastian, S., Phillip, L. E., Fellner, V. \& Idziak, E. S. (1996). Comparative assessment of bacterial inoculation and propionic acid treatment on aerobic stability and microbial populations of ensiled high-moisture ear corn. Journal of Animal Science 74, 447-456.

Silungwe, D., Millner, J. P. \& McGill, C. R. (2010). Evaluation of sorghum, sudan-grass and pearl millet cultivars in Manawatu. Agronomy New Zealand Journal 40, 1-10.

SinGH, B. R. \& SinGH, D. P. (1995). Agronomic and physiological responses of sorghum, maize and pearl millet to irrigation. Field Crops Research 42, 57-67.

Sivakumar, M. V. K., Das, H. P. \& BRUnini, O. (2005). Impacts of present and future climate variability and change on agriculture and forestry in the arid and semi-arid tropics. In Increasing Climate Variability and Change: Reducing the Vulnerability of Agriculture and Forestry (Eds J. Salinger, M. V. K. Sivakumar \& R.P. Motha), pp. 31-72. Dordrecht, Netherlands: Springer.

Sniffen, C. J., O'Connor, J. D., Van Soest, P. J., Fox, D. G. \& RusseLl, J. B. (1992). A net carbohydrate and protein system for evaluating cattle diets: 2. Carbohydrate and protein availability. Journal of Animal Science 70, 35623577.

Tilley, J. M. A. \& TerRY, R. A. (1963). A two stage technique for the in vitro digestion of forage crops. Grass and Forage Science 18, 104-111.

Tomich, T. R., Pereira, L. G. R., Gonçalves, L. C., Tomich, R. G. P. \& Borges, I. (2003). Características Químicas para avaliação do Processo Fermentativo de Silagens: uma Proposta para Qualificação da Fermentação. Documents Series Embrapa Pantanal 57. Corumbá, Brazil: Embrapa Pantanal.

Van Soest, P. J., Robertson, J. B. \& Lewis, B. A. (1991). Methods for dietary fiber, neutral detergent fiber, and nonstarch polysaccharides in relation to animal nutrition. Journal of Dairy Science 74, 3583-3597.

WARD, J.D., Redfearn, D.D., McCormick, M.E. \& Cuомо, G.J. (2001). Chemical composition, ensiling characteristics, and apparent digestibility of summer annual forages in a subtropical double-cropping system with annual ryegrass. Journal of Dairy Science $\mathbf{8 4}$, 177-182.

Weatherburn, M.W. (1967). Phenol-hypochlorite reaction for determination of ammonia. Analytical Chemistry 39, 971-974.

WeISS, W. P. \& WYATT, D. J. (2000). Effect of oil content and kernel processing of corn Silage on digestibility and milk production by dairy cows. Journal of Dairy Science 83, 351-358.

YADAV, O.P. \& Bidinger, F. R. (2008). Dual-purpose landraces of pearl millet (Pennisetum glaucum) as sources of high stover and grain yield for arid zone environments. Plant Genetic Resources: Characterization and Utilization 6, 73-78. 